\title{
Por real i reial por: el temor a morir emmetzinat a les corts reials mallorquina i catalana Antoni Contreras Mas
}

Cap al començament de la baixa Edat Mitjana es produeix una situació d'alarma generalitzada a totes les corts europees, provocada pel temor a morir emmetzinat. Aquest temor s'adverteix sobretot en les conductes i les actituds dels estaments més enlairats, ja que són aquells que es troben en condicions de deixar-ne testimoni. Per exemple, als inventaris de cases principesques i nobiliàries de les darreries del segle XIII, hi figuren nombrosos recursos materials per combatre els verins, com ara les pedres bezoars, que servien per detectar-los (Collard 1992).

L'ús i l'efecte dels verins eren prou coneguts des de ben antic. Eren considerats com a productes altament perillosos, que provocaven l'alteració de la voluntat de la víctima - és el cas, per exemple, dels filtres d'amor - o una mort quasi segura - funció dels tòxics o verins. En l'època clàssica es documenten nombrosos i cèlebres exemples de decessos presumptament causats per enverinaments. La mort de Sòcrates, que, condemnat a mort, acceptà beure un copa de vi emmetzinat amb cicuta per complir la sentència, és un dels casos més representatius. Un altre exemple conegudíssim és la sèrie d'enverinaments relacionada amb la família Júlia, de la qual provenien diversos emperadors romans. Entre els més famosos destaca el de l'emperador Claudi, ideat per la seva esposa i suposadament consumat amb Amanita muscaria i coloquíntida. També es pot mencionar el del seu fill Britànic, que fou assassinat pel seu germanastre Neró amb un vi emmetzinat.

El record d'aquests casos i d'altres semblants era ben present als segles medievals. A aquest record $i$ al coneixement de les propietats dels verins, s'hi sumen altres factors que provoquen un augment molt significatiu del temor a ser víctima d'un enverinament a les corts europees des del segon quart del segle XIII, com en tenim indicis sobretot a les pontifícies, la francesa o les del nord d'Europa. Amb tota probabilitat, aquesta onada de terror va ser parcialment provocada per notícies com ara el suposat enverinament de l'emperador Enric VII, el 1313, o l'intent d'assassinat del papa Joan XXIl pel mateix procediment el 1317. Si bé avui dia se sap que la causa de la mort de l'emperador fou la malària, el seu entorn personal va interpretar-la sense dubte com el resultat d'un enverinament. En un home de trenta-cinc anys, a la flor de la vida i de constitució robusta, el ràpid deteriorament de la seva salut resultava incomprensible per als seus fisici i per a l'entorn domèstic immediat: uns $i$ altres no li trobaren altra explicació que atribuir-la a un enverinament. Es creia que el verí havia estat administrat per cert confessor dominicà en el moment de combregar amb les dues espècies, pa i vi. La llarga tradició de 
vins medicinals apuntava al vi de la comunió com un vehicle idoni per introduir-hi el tòxic (Collard 2001).

Entre les causes subjacents d'aquests temors entre els poderosos s'ha considerat que la mala conjuntura econòmica i social i els terribles enfrontaments que se'n derivaven, feien viure, tant als estaments més alts com als inferiors, en un estat de temor permanent a ser víctimes d'un enverinament bé individual o bé collectiu. Malalties com la lepra o la pesta s'atribuïren a emmetzinaments d'aigües, aires o queviures. Des de l'epidèmia de pesta coneguda com la Mort Negra (1348), la majoria de metges atribuirren aquests reiterats episodis epidèmics a una corrupció per enverinament de l'aire, suposadament causat per conjuncions astrals malignes, però també per metzines fetes i disseminades pels leprosos, els jueus o altres grups marginals. La realitat era que l'amenaça del verí constituïa més un element de fascinació que una possibilitat vertadera de perjudici.

La importància que es concedia a la possibilitat de l'enverinament ja es reflecteix clarament a la legislació romana de les «XII Taules», que de-

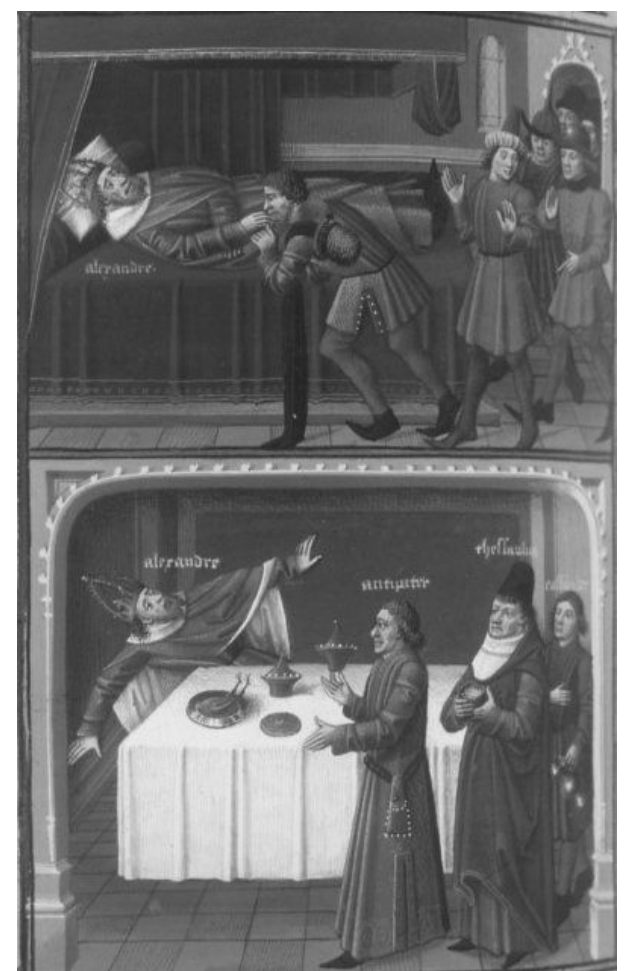

Antipater, i altres traïdors, enverinant Alexandre (Bibliothèque nationale de France, Français 50, f. 137vm detall). dicaven un article a determinar les penes en cas d'enverinament. Aquestes podien ser la deportació, la confiscació de béns o la mort. La Lex Cornelia de sicariis et veneficiis de Sila $(81 \mathrm{aC})$ completarà aquesta normativa, represa a l'Edat Mitjana per les Constitucions de Melfi, dictades el 1231 pel rei de Sicília i emperador Frederic II Hohenstaufen. En aquest cos legislatiu es fixà una pena pròpia $i$ específica per a aquesta casta d'homicidi: la forca. Certament era una pena severa, i també prou simbòlica i demostrativa que l'admissió de la possibilitat que el delicte es cometés no era contemplada amb lleugeresa pel jurista i el legislador. Així, la nova legislació introduiia una precisió jurídica, segons la qual es considerava també la punició de la temptativa d'administrar un simple filtre d'amor a algú. El dret romà, en canvi, només ho sancionava si la persona emmetzinada havia patit alguna lesió, mentre que quedaven sense càstig els intents que no haguessin estat consumats.'

\section{Els tractats sobre els verins}

La pràctica de la preparació i ús dels verins a l'Antiguitat queda testimoniada en diversos escrits, que demostren tenir notícies de diferents castes de productes més o manco verinosos o encisadors. Els més habituals eren d'origen vegetal, com el còlquic, l'acònit, l'ellèbor o la cicuta, per ventura la més coneguda d'ençà el cas de Sòcrates. N'hi havia també d'origen animal, com la cantàrida, insecte coleòpter fet pols, que s'usava com afrodisíac i que en realitat tenia un efecte vesicatori. Un dels autors antics que tracta el tema de manera més exhaustiva és Nicandre de Colofó, autor de dos textos fonamentals d'aquesta matèria, Alexipharmaca i Theriaca, que incorporen una llista dels animals verinosos i de diverses substàncies letals, de les quals descriuen les accions i els possibles antídots.

Podem observar la transmissió de la coneixença d'aquestes substàncies en obres de caràcter enciclopèdic, que bastiren els fonaments de la sistematització i jerarquització dels tòxics medievals, com el divulgadíssim Speculum naturale

\footnotetext{
1 Atrium-Histoire du Moyen Âge. Le XIV siècle. La peur du poison <http://www.yrub.com/histoire/peurpoison. $\mathrm{htm}>$.
} 
de Vicenç de Beauvais (m. 1248). Quan aquestes compilacions enciclopèdiques tracten dels verins, ho fan en els capítols dedicats a les serps i animals verinosos, tot descrivint el mode d'acció dels verins i els antídots generals. Així ho veïm, per exemple, a De propietatibus rerum, el popular tractat d'història natural de Bartomeu l'Anglès (c1190-1250), una de les compilacions més notables del segle XIII, i trobam el mateix criteri a De animalibus d'Albert el Gran (C1193-1280), un text de referència per als coneixements de biologia en època medieval. En canvi, els tractats específics es refereixen a emmetzinaments accidentals, derivats d'accidents o de picades o mossegades d'animals, però també a verins ingerits per via oral. En aquest sentit podem assenyalar el text de Juan Gil de Zamora (mort c1318) Contra venena et animalia venenosa. Redactat com a part de la seva enciclopèdia, cap a 1289-1295, constitueix un primer exemple europeu d'allò que es convertirà en un gènere específic de la tractadística. ${ }^{2}$

La generalització de la por individual i collectiva al verí ha estat posada en relació, al manco en part, amb la proliferació de tractats sobre aquesta matèria que es produeix cap a la segona meitat del segle XIV (Weill-Parot 2004: 87-88). Diversos tractats toxicològics, simplement titulats De venenis, copiats al llarg de tota l'Edat Mitjana, tenien com a preocupació principal establir una definició teòrica de què s'havia d'identificar com a un verí i com es diferenciava d'un medicament. La definició poc concreta del concepte grec de pharmakon, que tant designa un verí com un medicament (venenum ad sanandum), havia determinat que Avicenna (980-1037) intentés aclarir-ho, diferenciant què és un fàrmac medicinal i què o quan és o pot ser un verí. El seu Canon dedica una fen sencera del llibre IV, titulada De venenis, 3 exclusivament als verins: n'explica l'acció i descriu els remeis als quals es pot recórrer en cas d'in-

2 Sobre el tractat de Juan Gil de Zamora, vegeu Castro (1976) i Ferrero Hernández (2009a, 2009b i 2010).

3 Esta formada per cinc capítols, titulats: De radicibus ejus quod scitur de dispositionibus venenorum e bibitorum et distinctione sermonis in curationibus venenorum que non sunt ex animalibus; De venenis ebibitis que sunt ex animalibus; De morsione et punctura; De morsu hominis et quadrupedum; De punctura parvorum venenosorum. gerir-ne algun. La traducció d'aquesta monumental obra per Gerard de Cremona al darrer terç del segle XII convertí Avicenna en l'introductor d'una distinció clara entre verí i medicament. Serà l'adoptada pels autors llatins medievals des de finals del segle XIV, gràcies a la qual els metges van poder establir una classificació experimental de les substàncies farmacològiques (Chandelier 2009).

També a Averrois (c1126-1198), al manco en les edicions renaixentistes de les seves obres, s'atribueix un text sobre verins: De venenis (Lió, 1517). El catàleg de les seves obres, però, no en reporta cap amb aquest títol, si be és autor d'un comentari a Sobre la triaga de Galè. Tanmateix podem trobar una precisa distinció entre què és aliment, medicament o verí, en el comentari d'Averrois al text galènic Sobre les complexions. Al capítol III defineix com a aliment allò que el cos assimila i que transforma la seva naturalesa en la pròpia del cos, procés que rep el nom de nutrició. En canvi, els verins són considerats una de les dues formes dels medicaments. La seva acció consisteix en modificar la naturalesa del cos humà, alterant-ne la substància i transformant-la en la del verí. Això els diferencia dels medicaments que produeixen la transformació proporcionant al cos les qualitats que li són predominants, de forma que quan acaba el procés de transformació són assimilats pel cos i les qualitats queden esvaïdes. ${ }^{4}$

Les obres sobre matèria toxicològica reunien llistats de substàncies, de les quals enumeraven els efectes i els eventuals antídots. Entre els vegetals s'incloïen, a més dels ja esmentats, coneguts des de temps antics, alguns bolets i el baladre o llorer rosa. Entre els d'origen animal es consideraven la llebre de mar, mollusc en realitat inofensiu, les serps, els dracs, animals en descomposició i substàncies putrefactes mesclades amb sang. El capítol dels verins minerals es beneficià del desenvolupament de l'alquímia, preludi de la química, que proporcionava el mercuri, el coure, la pedra armènia, l'òxid de plom o l'arsènic. La preocupació es veu reflectida també en la recerca paral|lela d'antídots. Una recerca, assumida

4 Vegeu Vázquez de Benito (1987: 110) per a la «Paráfrasis expositiva sobre De la complexión, de Galeno». 
ràpidament pels metges, en què participaren figures tan cabdals com Avicenna, Maimònides o Arnau de Vilanova, tot identificant suposats detectors $i$ instruments que es creia que permetien identificar la presència de verí: tindran un valor excepcional per a aquesta finalitat les banyes d'unicorn, les banyes de serp, vulgarment dites llengües de serp, els betzoars o certes pedres precioses, que documentem amb freqüència $a$ les grans corts europees des de començament del segle XIV.

A l'àmbit peninsular destaca la setena obra de Maimònides, Sefer ha-samino Kitab al-sumwa-lmutaharriz min adwiya al-qattala (Llibre dels verins i del mode de protegir-se contra drogues mortals). La classificació que fa dels verins, diferenciats en calents i freds, i les descripcions dels símptomes d'enverinament, el convertiren en un text de toxicologia considerat modèlic a l'època. Fa recomanacions per tractar la mossegada de serp i descriu el llarg període d'incubació de la ràbia, per combatre la qual recomana deixar oberta la ferida per on va ser inoculada durant quaranta dies. Entre altres informacions destacables, ofereix alguns consells per evitar de ser enverinat (Rabbinowicz 1865 i Rosner 1968: 98-100). L'obra penetrà en l'àmbit català mitjançant la traducció de l'àrab al llatí d'Armengol Blasi, nebot d'Arnau de Vilanova i vinculat a l'Escola de Medicina de Montpeller, que la dedicà al papa Climent V. Un manuscrit d'aquesta traducció, titulat Tractatus Rabi Moyses Cordubensis [Maimònides] de medicinis contra venena, l'assenyala com a «translatus Barchinone... 1305» (Carreras Artau \& Batllori 1947: 20, 46 i 52).

S'ha apuntat la possible connexió de la traducció de Blasi amb les dues obres sobre verins atribuïdes a Arnau de Vilanova (1240-1311), intitulades Tractatus de venenis i Libellus de arte cognoscendi venena. ${ }^{5}$ Ambdues són d'autoria arnaldiana incerta, si bé la primera desperta dubtes més importants que no la segona. En el cas del Tractatus de venenis, els especialistes no han considerat que hi hagi prou arguments per confirmar o descartar l'atribució. En tot cas, de ser admesa com a obra autèntica d'Arnau, seria tardana, compos-

5 Sobre aquesta qüestió, vegeu McVaugh (1995), García Ballester, Salmón \& Sánchez Salor (1995) i McVaugh (1994). ta als darrers anys de la vida de l'autor. Reuneix una relació d'antídots simples i composicions dels tres regnes naturals i tota casta de receptes contra animals perillosos i intoxicacions. Destaquen sobretot les versions de noms d'espècies en llengües vulgars i sobretot en català, que vinculen el text amb l'entorn català. S'ha apuntat que, tal com la transmeten els manuscrits que ens han arribat, la composició de l'obra potser es deu a Pere Cellerer (Petrus Cellerarii), deixeble d'Arnau i metge a Daroca i Terol. És possible que aquesta compilació utilitzés fragments que Arnau no havia arribat a publicar i que Cellerer va ordenar i incorporar en una redacció final de l'escrit, de la qual ell mateix es va encarregar. En aquest sentit seria admissible considerar-lo un text arnaldià.

La segona obra és més breu i va ser impresa cinc vegades en la Itàlia del Quatre-cents. La primera a Pàdua, seguida de quatre més datades entre 1473 i 1476, una a la mateixa ciutat i les altres a Màntua, Roma i Milà. Està dedicada a proporcionar alguns consells sobre les precaucions per guardar-se dels emmetzinadors, passant de seguida a descriure els símptomes de la intoxicació i el seu tractament. La descripció clínica que ofereix és breu i clara i les terapèutiques proposades són racionals i precises. A grans trets, consisteixen en vomitius i neutralitzadors per als verins ingerits, i lligadures i cauteris per a les picades o mossegades d'animals verinosos. És, doncs, una monografia pràctica, sense gaire erudició, ni recursos màgics (Paniagua Arellano 1994: 70-71).

\section{Els banquets, moments d'alt risc}

Els verins orals solien administrar-se habitualment amb el suport d'una beguda o un menjar. Les denominacions de pols o poció, sovint presents en la documentació sobre aquests tòxics, denoten que la millor administració era a través d'una beguda, de preferència dolça 0 alcohòlica (Collard 1992:103). Això es deu al fet que «els sabors més dolços» dissimulen millor el verins, segons assenyala expressament l'expert toxicòleg Pere d'Abano (m. 1316). L'alcohol, per la seva banda, era considerat un potenciador de la difusió del verí per l'organisme, segons exposa Maimònides al seu tractat sobre verins. Si l'enverinador 
no tria un medicament per administrar el tòxic, que és un dels camins més apropiats per dissimular el gust desagradable o desacostumat del verí, Pere d'Abano indica que el procediment alternatiu és administrar-lo amb l'aspecte d'un menjar. ${ }^{6}$ Els verins podien incloure's en farinetes o sopes espesses, pebrades, aguisats, pa o fruites, entre les quals destaca la poma.

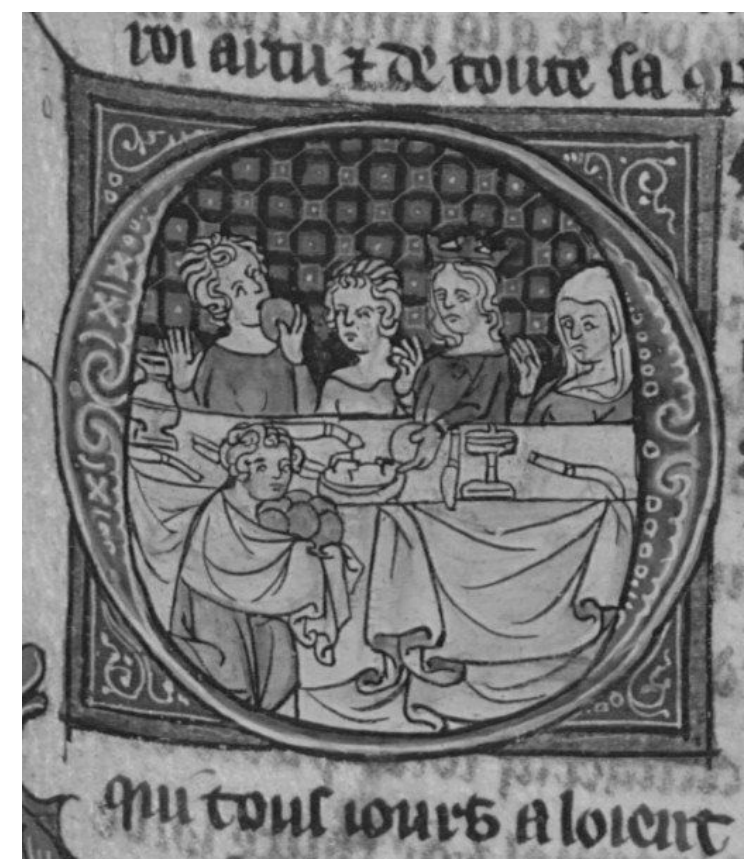

Com Avarlan envià una poma enverinada a la reina Ginebra, pensant que la donava a Galvany, i ella la donà a Gaherís el qual morí (París, Bibliothèque nationale de France, fr. 116, f. 692v).

Tot això justifica que els banquets fossin el lloc més habitual per dur a terme els enverinaments i que les cuines i taules dels poderosos, sobretot a les darreries dels segles medievals, fossen vistes com uns llocs particularment exposats. Així doncs, el temor als enverinaments podria haver posat fi als banquets públics de solemnitat, al manco en la forma en què es practicaven en els anys medievals (Collard 1992:104). A la comensalitat que comportaven es contraposava, però, una normativa reglada per una estricta precaució

6 Pietro d'Abano, De venenis atque eorum comodis remediis, redactat a finals del s. XIII i editat à Màntua el 1537. Vegeu Sodigne-Costes (1995), Collard (2013) i Corbella, Escudé \& Luna (2002). que imposava que tots els plats fossen tastats a la vista del príncep o senyor: era el conegut costum del tast, salva o essay. Aquesta por també havia determinat que els coberts i la sal fossen posats sota la custodia del mestre-sala, càrrec que es creà precisament en aquesta època.

És possible que d'ençà el coneixement i assimilació dels escrits esmentats a l'apartat anterior, les corts reials mallorquina i catalana prenguessin consciència del risc que suposaven els enverinaments, especialment durant els banquets, cosa que els va dur a adoptar mesures rigoroses per evitar aquesta amenaça. Resulta suggestiu també associar la data de la seva aparició amb els procediments judicials per emmetzinaments i intoxicacions: curiosament tots són posteriors a mitjan segle XIV. Cal citar en aquest sentit les anotacions del mestre racional de la cort catalana on manifesta haver rebut diverses quantitats de sospitosos, ja absolts, d'haver fet «fetilleries» O «metzines», pertanyen a 1358, 1392 i 1393 (Cardoner Planas 1971). Així mateix, els processos de la cúria judicial lleidatana que es refereixen a metzineres, es cursen el 1368, 1395 i 1398 (Camps i Clemente \& Manuel Camps i Surroca 1995b). Finalment, els deu processos criminals per intoxicació, seguits en aquest mateix tribunal, comencen pràcticament en el mateix període assenyalat $(1368,1372,1382,1385,1394$ i 1399) o amb lleu posterioritat (Camps i Clemente \& Manuel Camps i Surroca 1995a).

Així doncs, les corts reials mallorquina i catalana no van quedar exemptes del temor generalitzat a l'enverinament. En donen testimoni les repetides indicacions sobre aquest extrem que figuren a les Leges palatinae (Lleis palatines), redactades el 1337 pel rei Jaume III de Mallorca (1324-1349). Observem com les mateixes precaucions apareixen a les Ordinacions de la casa reial d'Aragó, del rei Pere el Cerimoniós confegides el 1344 a partir de les mallorquines. Dins d'un conjunt d'instruccions destinades a regular l'organització de l'etiqueta, competències i comportament en activitats de protocol públic dels servidors de les respectives cases reials, hi podem detectar tot un seguit de precisions que denoten la preocupació pels possibles enverinaments, tal com resseguirem a l'apartat següent. 


\section{La «infiltració de verins» a les corts reials}

Als ulls del rei de Jaume III, el risc de patir un enverinament per via alimentària al seu entorn era ben present. Ho demostren les referències de les Leges palatinae als casos de greus perills per la salut de reis i prínceps, patits a causa de la negligència i manca de fidelitat dels seus servidors immediats:

A causa de la nefandíssima infidelitat d'alguns ministres i de la seva negligència, que és enemiga de tot bé, i per la qual ometen les precaucions, hem sentit dir, moltes vegades, que tant als reis com als prínceps els han pervingut grandíssims perills, cosa que és més que summament horrenda i totalment contrària a la deguda fidelitat. (Pérez et al. 1991: 82/1; citem sempre la traducció catalana d'aquest volum)

Una via considerada molt adequada per fer arribar les metzines a la boca del rei eren principalment les begudes, en especial el vi, i en segon lloc els menjars. La diversitat de persones que feien part de la cadena que les adquiria, prepara-

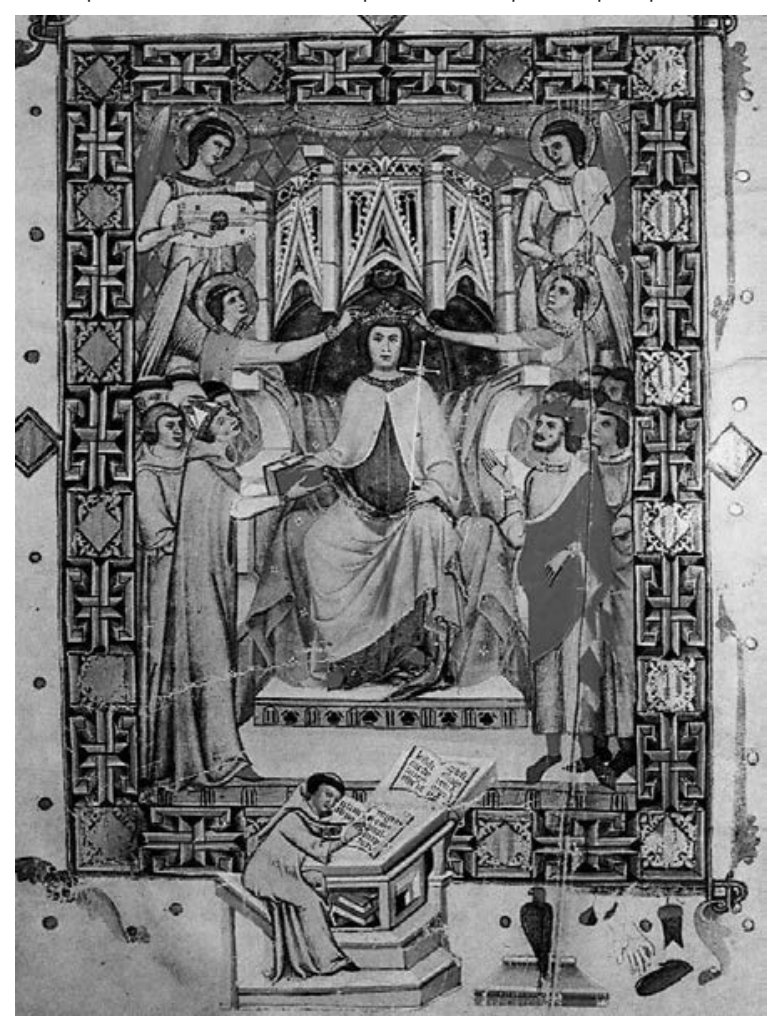

Coronació de Jaume III de Mallorca, detall de la miniatura inicial del Llibre de privilegis i franqueses (Palma, Arxiu del Regne de Mallorca, 1, f. 13ves, segle XIV). va i servia era difícil de controlar amb seguretat, cosa que posava el rei en situació de vulnerabilitat. Per aquest motiu es demanava que els servidors en fessin obligadament un tast abans de servir-les al rei:

Ja que les viandes amb què la nostra Altesa s'alimenta, generalment han de passar per diverses mans, abans que arribin a davant Nosaltres, ordenam fermament que els nostres escuders predits no deixin de tastar totes les viandes que ens han de servir, a pesar que ja les hagin tastat aquells qui subministraren dites viandes als nostres escuders mencionats. (Pérez et al. 1991: 8z/2)

La normativa dictada per Jaume III revela el possible paper del dimoni en aquests temors que congria, com evidencia la seva declaració explícita que

com més pròxims són els oficis de la cuina reial a la nostra persona, més gran deu ésser l'esment amb què s'han d'encomanar a persones fidels, a fi que l'inventor de tots els fraus, i enemic de tots els béns, el diable, amb el seu enginy mil-lenari, guarnit de moltíssims llaços i per la infiltració de verins, no pugui preparar calamitats a la salut dels homes. I consideram que és digníssim i necessari per a Nosaltres prevenir dits desastres (Pérez et al. 1991: 81/2).

A l'apartat on es regula l'ofici del fruiter i del seu ajudant, també fa ben explícita la seva intenció i finalitat de controlar els aliments que li siguin servits:

Per a totes les coses que se'ns proposen sobre els aliments, convé que, per a la seva adquisició, sempre l'assumesqui una persona vertaderament selecta, d'una fidelitat ben provada, que sia sagaç per distingir les coses millors, i sàpiga preveure el perill que, de tals coses, podria sobrevenir a la nostra persona. (Pérez et al. 1991: 97/2-98/1)

Un temor similar es detecta clarament a les Ordinacions de Pere el Cerimoniós i també el porta a adoptar mesures preventives. Com és sabut, el Cerimoniós concreta i defineix a la seva normativa tots els càrrecs $i$ comeses dels servents de la seva casa reial. En referència a les funcions de diversos càrrecs trobem abundants instruccions per evitar l'administració de verins al rei a través dels aliments, semblants a les precisions exposades a les Lleis palatines. En l'apartat referent al majordom, per exemple, es determi- 
na la seva obligació d'anar amb un porter a cercar el menjar del rei a la cuina i dur-lo a la taula reial, «per tal que tota perversa occassió de mesclar coses nocives en nostres viandes a qualque qual malvada persona sia tolta ab molt gran diligència per los damunt dits». Així mateix «totes les viandes que a Nós seran aportades diligentment tastar faça e d'aquí avant aquell mateix majordom d'aquelles metexes viandes faça tast» (Gimeno et al. 2009: 54).

El Cerimoniós estableix també que el majordom farà tastar també

al nostre boteller, panicer e reboster del vin e del pan e de fruytes e de les altres coses que per sos officis davant la nostra taula hauran aportades per rahon d'aministrar a Nós, d'aqueles ans que a Nós en la taula o en altre manera ne sien aministrades aja cura de donar tast e ell mateix pendre e de les aygues de les aygües de les mans a donar a Nós ans que sigam a taula sie tengut e d'aquella pendre e donar tast a aquell qui la portarà. (Gimeno et al. 2009: 54-55)

El rigor amb què aquestes mesures s'han de complir per part dels majordoms queda refermat amb l'exigència que tots prometin «per adjutori de sagrament» que:

sien obligats que aytant con poran e sabran esquivaran tots los perils que a nostra persona serien possibles endevenir, los quals encara perils a la notícia dels pervinents en qualque manera a Nós cuytosament manifestaran, e no han fet ne faran alguna cosa perquè a les coses desús promeses sens violació observadores puga obviar. E ells encara mayordòmens a Nós per sagrament tan solament prometre sien tenguts que ben e faelment l'offici lur exerciran. E con segons la nostra reyal ordonació dels consellers, los mayordòmens conseylers nostres sien enteses, volem que•l sagrament en la dita ordonació ordonat los desús dits mayordòmens nostres a Nós facen ab acabament. (Gimeno et al. 2009: 57)

A la cort mallorquina, una de les categories més destacades en l'organigrama dels servidors reials són els tres escuders qui ens serveixen les begudes. Segurament el motiu és la convicció que aquestes, especialment el vi, eren el vehicle més habitual dels verins orals, ja que, com hem vist més amunt, tractadistes tan importants com Pere d'Abano i Maimònides havien establert que la beguda, sobretot la sucrosa i l'alcohòlica era el millor mitjà per administrar el verí. En conseqüència, a l'apartat que descriu les competències i obligacions d'aquests servidors, es determina que els qui ocupin aquests càrrecs han de retre «homenatge $\mathrm{i}$ jurament de fidelitat» a la persona reial

prometent, de boca i amb les mans, que, amb tanta diligencia, procuraran, no solament conservar immune la nostra salut, sinó que, en quant puguin, allunyaran totes les coses contraries a la mateixa salut, i que, si els arriba alguna noticia de tals coses damnoses, ens la revelaran promptament; jurant també que no han fet ni faran, en el futur, cap cosa que els impedeixi complir dit jurament. (Pérez et al. 1991: 81/2)

Una mesura semblant és adoptada pel rei Pere el Cerimoniós en la regulació concernent a l'ofici de coper

sagrament, emperò, de faeltat e homenatge de bocca e de mans comendat a Nós façen que no tan solament la salut nostra illesa per lur poder conservaran. ans aytant com poran, les coses a ella contràries esquivaran et si a lur coneguda aytals coses esdevenien decontineut o intimaran, e que res no han fet ne d'aquí avant faran que no o puguen observar. (Gimeno et al. 2009: 59)

Un altre exemple d'aquestes mesures apareix a l'apartat que regula les obligacions «del boteller major $\mathrm{i}$ especial del nostre palau reial i del subboteller» de la cort mallorquina. En aquestes normes es determina que

el mateix boteller, alternant amb el subboteller, estiguin contínuament en dita botelleria. Per tal que puguin complir dits deures amb més perfecció i llibertat no sia que, vagant per defora, el seu ofici sofresqui detriment. (Pérez et al. 1991: 82/1)

La mesura forma part de les precaucions adoptades pel rei, a fi de no «descuidar la salut en Nosaltres que, en quant el Senyor ho permet, conduïm els nostres súbdits pel camí de la pau i de la salut». Per aquest motiu declara que

volem que, quantes vegades dit boteller subministrarà a dit escuder les coses esmentades, per a la nostra beguda, tantes altres vegades no deixi de tastar dita aigua i vi, separadament o mesclats, a fi que, si allà hi hagués aigua nociva, cosa que Déu no vulgui, puguem evitar el perill, i conservar la salut per al bé dels súbdits. (Jaume III 1991: 82/1) 
Aquests servidors, no tan sols han de fer el tast preventiu, sinó que a més han de vetlar per evitar que ningú, sobretot si és extern al servei reial, pugui tenir accés al rebost on s'hi estotjarà el pa, el vi o l'aigua. Encara més: han de vetlar «amb gran diligencia i atenció»

que ninguna persona que no pertany a l'ofici i sobretot, estranya, de cap manera s'acosti al rebost o a l'adreçador (el qual volem que estigui en el lloc més pròxim possible a la taula), i de ninguna forma toqui el pa, el vi o l'aigua que ens han de servir. Pérez et al. 1991: 82/1)

També ha de tenir esment que no es pugui afegir res de perillós per al rei o la gent del seu seguici a les coques o panets i neules («artocreis seu pastillis et nebulis») i altres coses

que en el forn o altres parts es preparen per a la nostra persona i per a la taula reial, tengui també molt d'esment, ensems amb el nostre flequer o panader, que es facin amb precaució, amb tota netedat, separadament $i$ en secret, per dit panader, a fi que no es pugui mesclar cap cosa nociva que podria perjudicar molt la nostra salut i la dels nostres súbdits. (Pérez et al. 1991: 82/1)

S'assenyala l'obligació de prometre sota jurament que preservarà la persona reial lliure de riscs i perills per a la seva salut i informarà de qualsevol notícia que tengui en aquest sentit:

dit boteller ens faci jurament de fidelitat i homenatge, sancionat de boca i amb les mans, que, en quant pugui, conservarà incòlume la nostra persona o la nostra salut, i extirparà radicalment les insídies contràries; $i$ que, si especialment per raó del seu ofici, tingués notícia que poden sobrevenir coses nocives a la nostra persona o a la nostra salut, immediatament ens la revelarà; i que no féu ni farà res que sia oposat al compliment de dites promeses. (Pérez et al. 1991: 82/1)

De manera similar, a les Ordinacions del Cerimoniós, en parlar dels botellers majors s'indica la obligació de fer els tasts corresponents cada vegada que li serviran aigua o vi, tant si en beu separadament o mesclats. Aquesta darrera opció revela la persistència del costum romà de mesclar aigua i vi per beure a taula, la proporció de la qual era competència del bibendi arbiter, evident avantpassat dels botellers medievals. El rei ho formula així: volem que tota hora que•l dit boteller al desús dit coper nostre les damunt dites coses per beure a Nós aministrarà (aytantes vegades dels desús dits aygua e vin separadament o ensemps) no tart de tastar per tal que si aquí alcuna cosa nociva, la qual cosa Deu no vuylla, hi havia pusca esquivar e la salut a profit de nostres sotsmeses conservar no oblit; ans sàviament e diligent se guart que negun al qual per son offici no pertanga e mayorment estrany al repositari o dreçador, lo qual la taula de l'argent és nomenada de vin e d'aygua en la dita taula o en altre loch ministrada, airear e tastar no jaquesca e d'aquí en nenguna manera per tractar. (Gimeno et al. 2009: 59-60)

El panader reial és un altre dels servidors immediats que ha d'oferir al rei de Mallorca les mateixes assegurances del compromís amb les seves obligacions, en idèntiques condicions que el boteller personal:

També esta obligat a prestar a Nosaltres i a un dels nostres majordoms, aquells jurament $i$ homenatge que, segons la nostra constitució precedent, el nostre boteller deu prestar a Nosaltres i a dit majordom. (Pérez et al. 1991: 82/2)

És el mateix compromís que han de contreure els botellers comuns, els quals són «obligats a retre, davant un dels nostres majordoms, el mateix jurament i homenatge que el nostre boteller especial deu retre davant Nosaltres». La finalitat de reclamar-los aquest compromís queda altre cop patent: que «en quant sia possible, puguem allunyar, de la nefanda ràbia, l'ocasió d'administrar-nos coses nocives» (Pérez et al. 1991: 83/1).

A la cort d'Aragó, el pastador és identificat com el servidor competent per fer «les panades, neules, empastats e altres coses que per la persona nostra o taula real en los forns o en altra manera s'apparellen, que sàviament e nédea se facen e separadament e secreta per lo pastador desús dit». La causa d'aquestes precaucions, una vegada més, és deguda al temor que «alcunes coses nocives mesclar no s'i pusquen que a la salut nostra e de nostres sotsmeses poguessen en alcuna manera obviarı.

Els tres portadors d'aigua a la botelleria de la cort de Jaume III de Mallorca, tenen les competències de «manipular l'aigua que després la nostra Serenitat ha d'usar»». Per aquesta raó el rei ordena 


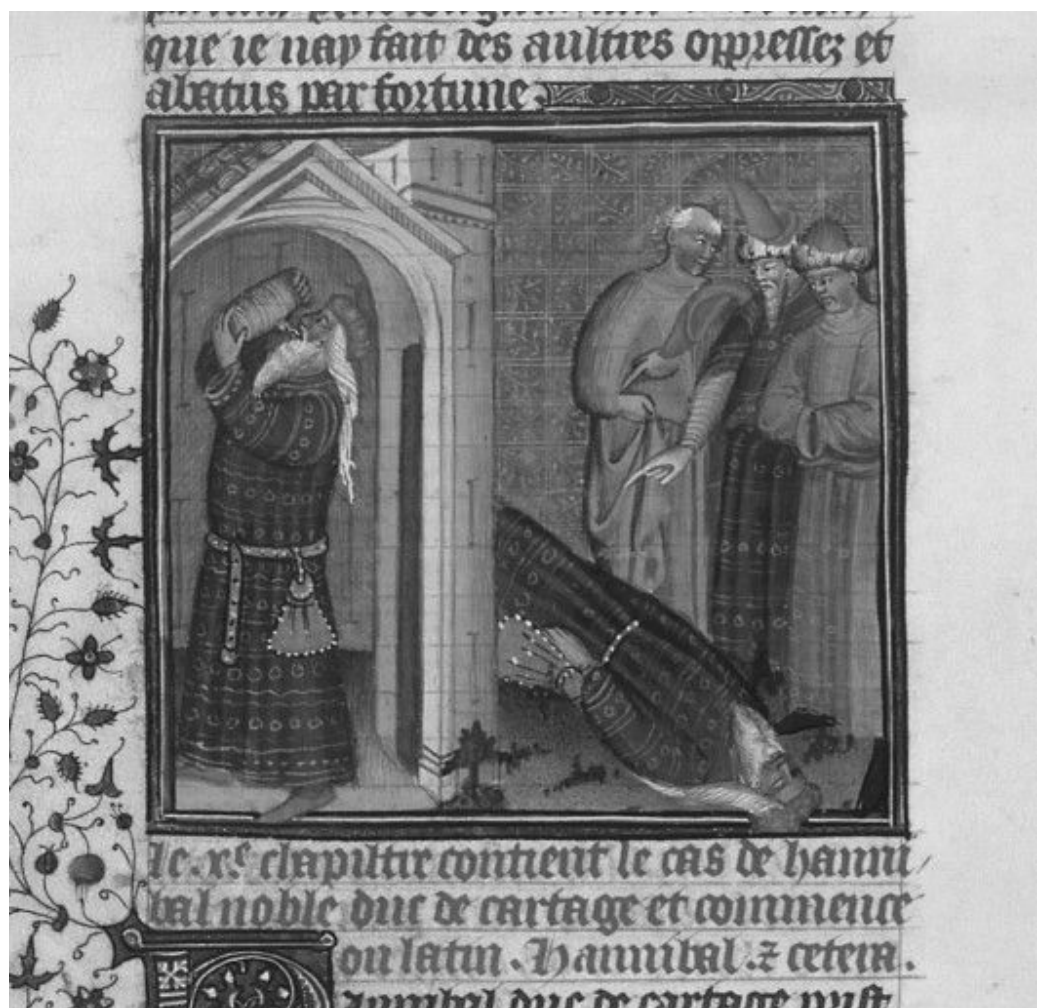

Suïcidi d’Anníbal amb verí (París, Bibliothèque nationale de France, fr. 226, f. 140 v). ens han de portar totes les viandes que pertanyen a l'escudella, i també altres aliments, quan i com als sia ordenat. (Pérez et al. 1991: 84/1)

A més de tot això són els que tenen el privilegi i deure de posar les viandes a la taula del rei, tant si n'han estat els portadors o les han rebudes d'altres servidors. Entre les seves obligacions es concreta que «quan han posat els aliments davant Nosaltres, els han de tastar immediatament». Per exercir aquest ofici, s'exigeix prestar jurament i homenatge a la persona reial, «en la forma expressada en el jurament que ens presten els servidors de les begudes» (Pérez et al. 1991: 84/1).

El comprador i el subcomprador són dos altres servidors essencials per a la protecció del bé públic a través de la conservació de la salut del príncep i de retruc la dels súbdits. Per això

que estiguin obligats a prestar, a un dels mestres del nostre alberg, el jurament i homenatge als quals estan obligats els nostres boteller i subboteller especials, tal com esta ordenat a una altra constitució nostra anterior. (Pérez et al. 1991: 83/1)

Especialment imperativa és la precisió referent als scuders «destinats a tallar les viandes davant nosaltres» en la cort mallorquina:

Ja que les viandes amb què la nostra Altesa salimenta, generalment han de passar per diverses mans, abans que arribin a davant Nosaltres, ordenam fermament que els nostres escuders predits no deixin de tastar totes les viandes que ens han de servir, a pesar que ja les hagin tastat aquells qui subministraren dites viandes als nostres escuders mencionats [...] per això ordenam que ens facin un jurament $i$ homenatge semblants als que estan inclosos en les ordenances anteriors. Pérez et al. 1991: 8z/2)

Sobre els tres o quatre portadors de l'escudella reial, diu el rei mallorquí que

qualsevol d'ells sien superiors a aquells qui serveixen en la nostra cuina, i que els puguin manar les coses que els pareguin convenients. Però no donin permís per treure cap cosa fora del nostre alberg. [Són] els qui les lleis i els edictes dels prínceps disposen que [...] la cura de comprar carn correspongui a una persona principal [...] especialment a determinades persones fidels a ell, les quals complesquin els seus oficis amb la màxima diligència. (Pérez et al. 1991: 84/2)

Ambdós funcionaris compraran «fidelment la carn, peix i altres comestibles [...] i altres coses que sien o seran necessàries tant per a Nosaltres com per als nostres domèstics». Quan les facin

coure i preparar amb la màxima sollicitud, i amb la precaució que ni en el tallar dita carn, ni d'altra manera, es pugui cometre cap fraudulència, i que totes $i$ cada una de les viandes es preparin bé i decentment, com correspon a la cort. (Pérez et al. 1991: 84/2)

Per aquest motiu Jaume III manifesta la seva voluntat «que el comprador tasti els nostres comestibles, abans que els nostres servidors els portin davant la nostra presencia» (Pérez et al. 1991: 84/2).

Els dos cuiners personals del monarca, òbviament, també són instats a vetlar per la seguretat dels aliments i plats que se serviran a la 
taula reial. L'apartat que els dediquen les Lleis palatines concreta que

\begin{abstract}
per evitar més segurament els perills, amb la present ordenació, volem establir que s'assumesquin per a la nostra cuina especial, dos cuiners, homes bons i fidels, que han de ser elegits per nosaltres, i deuen esser cientifics $i$ experts en dit ofici. Aquests cuiners deuran preparar els aliments que s'han de consumir per Nosaltres i per aquells que la nostra Serenitat voldrà escollir. I els han de preparar amb la màxima atenció, cautament, $i$ amb netedat, de tal manera que dits aliments s'aparellin en lloc segur, secret $i$ bastant apartat, a fi que no hi entrin més que poques persones, $i$ així s'allunyi, tot quant sia possible, l'ocasió d'infiltrar verinades. I quan els aliments es deuran portar a davant Nosaltres, no deixin de tastar-los. (Pérez et al. 1991: $85 / 1$
\end{abstract}

Com en els altres casos ja esmentats en aquest llistat de professionals relacionats amb l'alimentació reial, els «dits cuiners ens han de retre jurament i homenatge semblants als que ens deuen prestar els nostres botellers especials». L'ordinació determina que «a fi que, si estan vagant per defora, el seu ofici no patesqui detriment, ordenam que un dels dos cuiners jegui dins el nostre alberg, en la cuina especial o prop d'aquesta» (Pérez et al. 1991: 85/1). Aquesta exigència seria l'evident justificació de l'existència de unum lectum plegadisum, a l'inventari dels mobles de la cuina reial del Palau de l'Almudaina de Palma, fet el 1332 (Durliat 1989: 186, 192 i 195). La seva presència, que altrament seria difícil d'explicar, segurament es pot atribuir a l'aplicació d'aquest punt de les Lleis palatines. Els cuiners comuns, és a dir els que preparaven el menjar per a la resta de membres de la casa reial, havien així mateix de prestar «jurament i homenatge als nostres majordoms, tals com els que ens presten els cuiners del nostre sustent» (Pérez et al. 1991: 85/2).

L'argenter de la cuina reial havia de prestar jurament i homenatge com feien «a més dels majordoms, els nostres escuders encarregats de portar la nostra escudella, i dits comprador i subcomprador»». Les seves obligacions queden descrites així:

cada dia a les hores degudes, no deixi d'encendre foc en dita cuina, i posi, damunt els fogons, les olles i calderes, amb aigua. També desplomi les gallines $i$ aus volàtils, i renti i netegi les altres carns i els peixos; cuidi de fer girar els rostidors i d'ajudar diligentment a dits servents de la nostra cuina, tal com li sia preceptuat i manat per ells o pel comprador o subcomprador. A més, volem que ell dugui i porti a la mateixa cuina l'aigua necessària per preparar solament els nostres aliments. (Pérez et al. 1991: 85/1)

El museu o reboster era un dels dos cuiners de la boca reial. Les seves competències contemplaven l'aprovisionament del rebost reial de

sucre, gingebre i altres espècies picades, mel, oli, i també carn salada, formatges, peixos salats, vinagre, sagins $i$ altres comestibles semblants que es puguin o se solen conservar, comestibles i que sien convenients per preparar dites viandes. (Pérez et al. 1991: 86/1)

Tenia sota la seva responsabilitat

la clau del rebost o reservador de la nostra cuina, i endemés, cada dia, les carns que el comprador o subcomprador hagin adquirit i portat a la cuina, no deixi de repesar-les fidelment abans de tallar-les. (Pérez et al. 1991: 86/1)

Entre les seves obligacions, una vegada «repesades aquestes carns, tal com s'ha assenyalat», hi havia la de tallar-les i trossejar en diverses porcions, fent altre tant amb els peixos. Les porcions comprades i trossejades expressament per la persona reial, havia d'entregar-les directament als cuiners privats, «a fi que preparin i coguin les viandes per a la nostra mateixa persona». Les altres carns, «comprades i tallades per als nostres domèstics, anirien als cuiners encarregats de preparar-les i coure-les per a dits domèstics». Les carns que s'havien de preparar per al rei, s'havien de manipular, repesant-les i tallant-les, «solament quan estiguin presents les persones anomenades abans, a fi d'apartar tota sospita que s'hi hagin mesclat substàncies nocives». Com la resta dels servidors amb accés directe a la persona reial, era obligat a prestar «jurament i homenatge, tal com l'altre cuiner destinat a preparar les nostres viandes» (Pérez et al. 1991: 86/1).

Els escuders portadors del tallador reial transportaven el tallador exclusiu del rei directament a la taula reial, però no l'hi podien dipositar, cosa que era competència del portador de la escudeIla. Quan arribaven davant el rei, havien d'esperar que aquest altre servidor se'n fes càrrec, ja que 
només ell estava autoritzat a posar el plat sobre la taula reial. Una vegada tallades les carns, generalment rostides, que solien servir-se sobre els talladors, s'havien de«donar a tastar aquelles, a fi que Nosaltres i ells mateixos estiguem lliures de tota sospita d'insídies». El jurament i homenatge que estaven obligats a fer a la persona reial era el mateix que prestaven «els destinats a servir-nos les begudes» (Pérez et al. 1991: 1991: 86/2).

Podem concloure, doncs, que la totalitat dels servents d'ambdues cases reials havien de prestar jurament i homenatge, bé directament al rei o bé al majordom, de vetlar per evitar possibles intents d'enverinament del rei. La normativa que els hi obligava com un dels seus deures principals constitueix un clar testimoni de la por de la reialesa davant la possibilitat de ser enverinats durant un àpat.

\section{A manera de conclusió}

Arran d'algunes morts en els entorns aristocràtics i reials, inexplicables segons els coneixements de l'època, es produí una preocupació en aquests cercles davant de la possibilitat de ser enverinat. La recuperació i divulgació de narracions sobre casos famosos d'entuixegaments en època clàssica contribuí a crear aquesta preocupació social.
Parallelament, o com a conseqüència d'aquesta por, diversos autors del món mèdic, àrab i cristià, dediquen la seva atenció a tractats d'aquesta matèria. La percepció d'aquesta amenaça arribà a les corts reials mallorquina i catalana, de manera parallela a la dedicació d'alguns tractats d'aquesta matèria per part d'autors vinculats a l'Escola de Medicina de Montpeller: destaquen entre aquestes obres dues d'atribució dubtosa a Arnau de Vilanova, una traducció del seu nebot Armengol Blasi i la possible contribució d'un deixeble d'Arnau anomenat Pere Cellerer. La preocupació per la possibilitat de ser enverinat es reflecteix profusament en les Lleis palatines de Jaume III de Mallorca i les Ordinacions de Pere el Cerimoniós. En aquestes dues normatives, que regularen tot allò que feia referència al protocol i normativa de la vida curial a ambdós entorns, hi figuren repetides allusions a les precaucions que s'han d'adoptar per prevenir l'enverinament. Tots els servidors que tenien contacte directe amb el rei, els productes que se servien a la seva taula o els preparaven, tenien l'obligació de prestar jurament de lleialtat a la persona reial. La reglamentació els comprometia a vetlar per la protecció de la persona i família reial, amb el mateix nivell d'obligació i rigor que els homes d'armes.

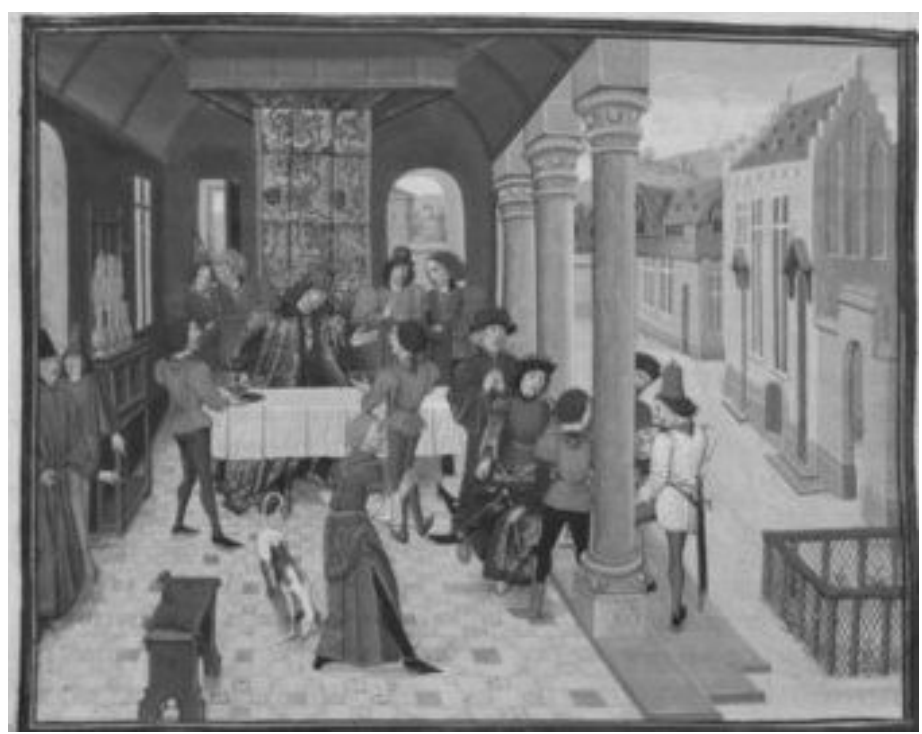

Alexandre enverinat a la taula (París, Bibliothèque nationale de France, fr. 22547, f. 255 v). 


\section{Bibliografia citada}

Camps I Clemente, Manuel \&

Manuel CAMPS I SURROCA, 1995a:

«Característiques de les intoxicacions a Lleida durant la Baixa Edat Mitjana»,

Gimbernat, 24, 113-130.

Camps I Clemente, Manuel \& Manuel CAMPS I SURROCA, 1995b: «Metgesses, metzineres i dones remeieres a la Lleida del segle XIV», Gimbernat, 24, 103-112.

Cardoner Planas, Antonio, 1971: «Personajes de alcurnia y hechicerías en la casa real de Aragón», Medicina e Historia, 74, 5-15.

Carreras Artau, Joaquim \& Miquel BATLLORI, 1947: «La patria y la familia de Arnau de Vilanova»», Analecta Sacra Tarraconensia. Revista de Ciencias Historico-Eclesiasticas, 20, 5-75.

CASTRO, Manuel de, 1976: «Johannes Aegidii Zamorensis OFM, Contra venena et animalia venenosa (introducción, edición, notas)», Archivo Ibero-americano, 36, 3-116.

ChANDelier, Joël, 2009: «Théorie et définition des poisons à la fin du MoyenẦe», Cahiers de Recherches Médiévales. A Journal of Medieval Studies, 17, 23-38.

Collard, Franck, 1992 : «Recherches sur le crime de poison au Moyen Âge», Journal des savants, 1, 99-114. doi : 10.3406/jds.1992.1553 http:// www.persee.fr/web/revues/ home/prescript/article/jds_oo218103_1992_num_1_1_1553

Collard, Franck, 2001: «L'Empereur et le poison: de la rumeur au mythe. À propos du prétendu empoisonnement d'Henri VII en 1313», Médiévales, 41, 113-131. doi : 10.3406/medi.2001.1528 http:// www.persee.fr/web/revues/ home/prescript/article/medi_07512708_2001_num_20_41_1528

Collard, Franck, 2013: «Le De venenis de Pietro d'Abano et sa diffusion: d'une traduction française à l'autre (1404-1593)», Médecine, astrologie et magie entre Moyen Âge et Renaissance: autour de Pietro d'Abano, ed. J.-P. Boudet, F. Collard i N. Weill-Parot, Florència: Edizioni del Galluzzo, 203-230.

Corbella, Jacint, Manuel Escudé \& Margarida LUNA, 2002: «La obra toxicológica de Pietro d'Abano», Històries dels verins i els seus estudiosos, Barcelona: Seminari Pere Mata, Universitat de Barcelona, 159-166.

DURLIAT, Marcel, 1989: L'art en el Regne de Mallorca, Palma: Moll.

Ferrero Hernández, Cándida, 2009a: El «Liber contra uenena» de Juan Gil de Zamora, Barcelona: Reial Acadèmia de Bones Lletres de Barcelona.

Ferrero Hernández, Cándida, 2009b: «Regimen sanitatis zelantibus? Le Contra venena de Juan Gil de Zamora», Cahiers de Recherches Médiévales. A Journal of Medieval Studies, 17, 7-30.

Ferrero Hernández, Cándida, 2010: «Nuevas perspectivas sobre Juan Gil de Zamora», Stvdia Zamorensia, 9, 19-33.

García Ballester, Lluís, 1995: «Hacia el establecimiento de un canon de las Obras Médicas de Arnau de Vilanova», Arxiu de textos catalans antics, 14, 23-29.

García Ballester, Lluís, Fernando SALMÓN \& Eustaquio SÁNCHEZ SALOR, 1995: «Tradición manuscrita y autoría: sobre la posible autenticidad del comentario de Arnau de Vilanova al De morbo et accidenti de Galeno»), Arxiu de textos catalans antics, 14, 31-74.

Gimeno Blay, Francisco M., Daniel GozAlbo \& Josep TRENCHS (eds.), 2009: Ordinacions de la Casa i Cort de Pere el Cerimoniós, València: Universitat de València - Acadèmia Valenciana de la Llengua.
McVaugh, Michael R., 1994 : «Petrus Cellerarius discipulus Arnaldi de Villanova», Comprendre et maitriser la nature au Moyen Age: Mélanges d'histoire des sciences offerts à Guy Beaujouan, Ginebra: Droz, 337-350.

McVaUGH, Michael R., 1995: «Two texts, one problem: the authorship of the Antidotarium and De Venenis attributed to Arnau de Vilanova», Arxiu de textos catalans antics, 14, 75-94.

Paniagua Arellano, Juan A., 1994: El maestro Arnau de Vilanova médico, Barcelona: Fundació Uriach, $2^{\mathrm{a}}$ ed. corregida. [ $1^{\text {a }}$ ed. Valencia: Cuadernos Valencianos de Historia de la Medicina y de la Ciencia, 1969].

Pérez et AL., 1991: Lleis palatines, presentació i transcripció de Llorenç Pérez Martínez, introducció de Gabriel Llompart i Marcel Durliat, traducció de Miquel Pascual Pont, I, Palma: Olañeta.

RABBINOWICZ, Israël-Michel, 1865: Maimònides, Traité des poisons, París: Delahaye.

Rosner, Fred, 1968: «Moses Maimonides. Teatrise on Poisons», Journal of the American Medical Association, 205.13, 214-216.

SOdigne-Costes, G., 1995 : «Un traité de toxicologie médiévale: le Liber de venenis de Pietro d'Abano (traduction française du début du $X V^{e}$ siècle)», Revue d'histoire de la pharmacie, 42, 125-136.

Vázquez de Benito, M. Concepción, 1987: La medicina de Averroes: Comentarios a Galeno, Salamanca: Colegio Universitario de Zamora.

Weill-PAROt, Nicolas, 2004: «La rationalité médicale à l'épreuve de la peste: médecine, astrologie et magie (1348-1500)», Médiévales, 46 (printemps), 73-88. 